\title{
The information society in South Africa: from global origins to local vision
}

\author{
Mary Nassimbeni \\ School of Librarianship, University of Cape Town, Private bag, Rondebosch, 7700 Republic of South Africa \\ mcn@education.uct.ac.za
}

\begin{abstract}
The origins and evolution of the concept of the information society are sketched with a view to assessing the extent of its development in South Africa. Key features of the concept are outlined as expressed in seminal writings, global conferences, and declarations from prominent proponents such as the European Union and the G7 group of nations. Using the application of information communication technologies (ICTs) as an important benchmark, the situation in developing countries, including South Africa, an important regional leader, is explored. Opportunities for library and information services in the realisation of an information society in South Africa are identified, highlighting in particular the creation of partnerships in the development and spread of Multi-Purpose Community Centres (MPCCs).
\end{abstract}

\begin{abstract}
Die oorsprong en evolusie van die konsep van 'n inligtingsgemeenskap word geskets met die doel om vas te stel in watter mate dit reeds in Suid-Afrika ontwikkel het. Sleutelkenmerke van die begrip 'inligtingsgemeenskap' word omskryf soos dit reeds uitgedruk is in kerngeskrifte, wêreldkongresse en verklarings van belangrike voorstanders soos die Europese Unie en die G7-nasies. Die toepassing van inligtingskommunikasietegnologie word as 'n belangrike maatstaf gebruik om die toestande in ontwikkelende lande, insluitende Suid-Afrika, te ondersoek. Geleenthede vir biblioteek- en inligtingsdienste vir die daarstelling van ' $n$ inligtingsgemeenskap in Suid-Afrika word geïdentifiseer. In die besonder word die skep van vennootskappe in die ontwikkeling van veeldoelige gemeenskapsentrums beklemtoon.
\end{abstract}

Daniel Bell is one of the authors usually closely associated with the development of the concept 'information society', since he sketched the essentials of post-industrialism in his book, The coming of the post-industrial society (1974). While he did not use the term information society in this book, his prediction that information would become the key economic factor in modern societies has been very influential in the USA and many other countries which he saw as poised on the cusp of the information age. The concept was popularised by futurists such as Toffler (1980) and Naisbitt (1984) in their writings of the 1980s. In the 1990s, political policy makers in the west took the concept seriously, to the extent that today it has been given expression in the public policy sphere, reflected and analysed in the section below which teases out the significance for South Africa and the rest of the continent of a number of key inter-governmental conferences and declarations, for example by the G7 and the European Union.

Any attempt to measure the extent to which a country has moved towards being an information society would necessarily depend on an operational definition. Although very few operational definitions exist, the following representative definitions provide useful pointers to aspects which need to be considered in the exploration of the term and its application to the situation in South Africa. The compilers of a report on the information society in European public libraries propose the following definition to guide their contributors and rapporteurs from different European countries in their discussion of the role of the public library in the information society in their respective countries.

'The term is used here to characterise a situation where IT is integrated in industrial production and in information dissemination in all fields, one in which technology establishes completely new premises for the production, distribution and consumption of information and the creation of knowledge' (Thorhauge et al. 1997:8).

Finland's Council of State defined the information society in 1995 as a

'society which makes extensive use of information networks (meaning systems of IT hardware and services which provide users with delivery and retrieval services in a given area, e.g. electronic mail, directories and video services) and IT (information technology meaning the hardware, software and methods used for the automatic processing and transfer of data, and skills needed to use them), produces large quantities of information and communication products and services, and has a diversified content industry' (quoted by McColgan 1996).

A European Union document describes the information society as follows:

'The information society is the society currently being put in place, where low-cost information and data storage and transmission technologies are in general use. This generalisation of information and data use is being accompanied by organisational, commercial, social and legal innovations that will profoundly change life both in the world of work and in society generally' (European Union, High-Level Expert Group 1997)

From these quotations it is possible to extract a number of salient points:

- the importance of information, and the creation of new knowledge;

- the prominence of the expanded role of IT in the production and dissemination of information;

- the use of information networks for the distribution of information; 
- the radical changes in people's lives that are being wrought by increasing integration of information communication technologies (ICTs) into all spheres of public and private life; and

- the imperative for citizens to be trained in new skills to allow them to benefit from their access to and use of a massively expanding store of information.

Information is central to the post-industrial society which sees a shift away from the industrial economy based on manufactured goods to an information-based service-oriented economy. The converging technologies of electronic data processing and telecommunications are making the revolution possible. The advanced economies have become informationintensive, are undergoing major structural changes and are making massive investments in information and telecommunications infrastructure and technologies. The diffusion of information technologies to all areas of human life is having a major impact on all spheres of life. Webster (1995) has usefully summarised a set of propositions about the information society:

- knowledge and information consume more of the societal activity than the production of goods;

- social organisation is around information rather than material production;

- the major basis for the information society is defined by the shift in economic activity;

- information and computing power are the key resources in the information economy;

- the function of these resources is to amplify mental labour; and

- the leading industries are knowledge industries.

The rapid advances made in the information and communications technology field have provided great impetus for the development of the idea of the Information Society. The European Union has issued a number' of important policy statements about the information society, for example the influential Bangemann Report, entitled 'Europe and the Global Information Society' (Bangemann et al. 1994). While the European Union was developing its vision and strategies for the information society in Europe, similar initiatives were being undertaken in the Untied States, Canada and Japan. At the same time that the Bangemann Report was being released, the United States were unveiling their plan for the National Information Infrastructure Initiative (NII) (Bangemann 1995). Many of these policy documents highlight the opportunities new ICTs can offer such as increased productivity, improved competitiveness, energising 'every economic sector' and the emergence of new products and services (European Union, High-Level Expert Group 1997). The technological revolution sees the rapid and wide application of ICTs which offer tools and services in the workplace, at educational institutions and in the home (European Union 1996).

These potential benefits of the use of ICTs in accelerated social and economic development, have naturally raised the question of the risks or penalties for slow or no take-up of
ICTs in particular countries. Globalisation and international competition are forcing countries that are lagging behind technologically to consider the dangers of lagging behind forever. A European Union document reflects on the unequal rate of introduction and application of ICTs:

'Advanced countries are rapidly pursuing their version of the [information society] agenda, and developing countries must do as well or risk exclusion from a global economy and severe disadvantage' (Bangemann 1994).

The South African government, in particular Deputy President Thabo Mbeki, has been instrumental in pointing out to developed countries that their pursuit of the ideals of the global information society oblige them to consider the needs of the developing countries. These initiatives and the role of South Africa are sketched below.

\section{Milestones in the development of the information society in South Africa}

Some of the significant milestones in the development of the concept of information society in South Africa have been:

- the G7 conference, Brussels, February 1995;

- the Information Society and Development (ISAD) Conference, Midrand, May 1996; and

- International Telecom Union Africa Telecom '98, Johannesburg, May 1998.

In a well-publicised conference in 1995 the G7 nations extended their concern to questions about its impact on developing countries. The G7 Ministerial Conference took as its theme in 1995 'The information society', based on their shared belief that 'the smooth and effective transition towards the information society is one of the most important tasks that should be undertaken in the last decade of the 20th century' (G7 Ministerial Conference ... 1995). The conference endorsed a number of core principles which would guide the world's entry into the information age. These included reaching a balance between the role of the private sector, which is to make investments for the rapid development of infrastructure and services, and the role of public authorities which have to define a clear regulatory framework, and promote the social and cultural dimension. In an unusual precedent, Deputy President Thabo Mbeki was invited to address the conference. In his address Mbeki made a plea to the developed countries to allow the developing countries an opportunity to participate in the information society and to share in its benefits. He noted that they would require assistance from the richer nations to do this. In a speech delivered to the conference, Deputy President Mbeki outlined the South African government's approach to the evolution of the information society in South Africa:

- a belief that ICTs constitute an engine for economic growth;

- the commitment to building a strong information infrastructure in South Africa, as seen as an integral part of the region of Southern Africa; 
- the global dimension of the solutions demand a crosssectoral approach;

- that the recognition of the importance of infrastructure should not deflect concern that developing countries need to be not only consumers, but producers of information and knowledge; and

- the building of the information infrastructure will rely on international co-operation (Mbeki 1995).

In the concluding statements after the conference, the Chair noted that developing countries would be assisted to join the revolution and by so doing would have the opportunity "to leapfrog stages of technology development and to stimulate social and economic development' (G7 Ministerial Conference ... 1995). The G7 Conference agreed to ensure that the information society would be a global movement by assisting the less economically developed nations to share in the benefits.

The G7 Conference is significant for the development of attitudes and approaches in South Africa; some of the ideas and conceptions emerging from this conference resonate in the deliberations of the Information Society and Development Conference in May 1996, which was held in response to a proposal by Deputy President Mbeki that a special conference be devoted to addressing issues faced by developing countries in the emerging information society. One of the ideas was that the use of ICTs could accelerate economic and social development in developing countries, and to ensure their effective participation in the global information economy (Chairperson's views concerning ideas ... 1996). The themes proposed by the conference which would be linked to G7 pilot projects that have been extended to developing countries were:

- integrated systems to meet people's needs;

- universal access;

- innovation to support appropriate applications and content;

- human resource development;

support for business, especially SMMEs;

support for good governance;

- cultural heritage;

- building the infrastructure; and

- countries with special circumstance (Chairperson's views concerning ideas ... 1996).

Some of these themes will be elaborated and commented on in relevant sections below.

The focus of the conference was on ways that developing countries could harness the use of ICTs to their economic and social development particularly given the high levels of poverty in these countries. The European documents, for example, hardly refer to the problem of poverty, but caution against the risk of social exclusion, or the development of a two-tier society determined by access to and possession of information technology and information skills.

The Africa Telecom Conference held in South Africa in 1998 gave an opportunity to African telecommunications ministers to confer on the increased role of ICTs in develop- ment in a continent which, with the exception of South Africa, is on the margins of the information age because of, among other factors, the low rate of Internet connectivity (Amoako \& Faye 1998:18). African countries will have to create a policy climate to optimise the use of ICTs for development as outlined by Kofi Anan:

- Improvement in infrastructure and technology for the promotion of greater, freer and more equitable access to information.

- Lifting of government monopolies and censorship.

- Faster and more effective transfer of technology through greater communication between the developed and the developing world.

- The promotion of knowledge through new and culturallysensitive approaches to learning and education.

- The creation of new knowledge through the encouragement of foreign investment.

- The establishment of pilot projects in fields such as distance education, telemedicine, telebanking, microcredit schemes, environmental protection and management.

- Prioritising the needs of the young for information and knowledge (Amoako \& Faye 1998:18).

These challenges are as pressing for South Africa as for the rest of the continent. The content of the Internet, for example, is heavily biased towards speakers of English, with a European or American bias. The lack of relevant and local content to address the realities of the environment also militates against the principle of nurturing linguistic and cultural diversity. The backlog in provision of facilities in public institutions such as schools and libraries means that there is also a slow take-up of the skills required to exploit opportunities for lifelong learning.

\section{Telecommunications infrastructure in South Africa: the leapfrog approach}

The discourse has moved beyond the rehearsal of the benefits of joining the information society, to attempts to find the means and methods. The implementation strategies used by governments in Africa (including South Africa) are often framed by the 'leapfrog theory' of advancement. While South Africa appears to be in a favourable position relative to many African countries with respect to connectivity, there is a great imbalance as is shown in the following figures for telecommunications infrastructure:

'South Africa is the 14th largest user of the Internet in the world, with state-of-the-art communication systems (including cellphones) in many urban areas. In most rural areas, however, there is very poor service, with many South Africans never having made a phone call. The number of phone lines per hundred (teledensity) is $9,5 \%$ overall for South Africa. In some wealthy suburbs this figure goes up to 50, whereas in parts of the Eastern Cape the teledensity is around $0,1^{\prime}$ (Butcher 1998). 
The latest estimate is that there are 800000 Internet users in South Africa, in comparison to 80000 in the rest of the continent. This means that about one in 65 persons in South Africa is connected, as compared to one Internet user per 45 people globally, against one in six in Europe and North America. The figure for the rest of Africa is one in 5000 people (Gumede 1998:5). Low personal incomes in Africa (including the majority of people in South Africa) suggest that personal investment is unlikely and that the government will have to intervene (as it has started to do) to make sure that public facilities are available.

Butcher points out the enormous disparities that exist, among schools, for example, should not inhibit projects that seem small in comparison to the huge need. He quotes dismal statistics from the schools audit that illustrate the huge task in a single sector:

'The School Register of Needs indicates that only 43 percent of schools have electricity and only around 38 percent have telephones. Further, it is estimated that 82 percent of schools have no media equipment, 72 percent no media collections, 73 percent no learning equipment, and 69 percent no materials' (Butcher 1998).

Many articles, papers and commentaries concerned with the information society devote much of their space to discussions around the role of ICTs, offering ICTs simplistically as the vehicle for social and economic empowerment, development, and redistribution. Hafkin (1996), an advisor on many African Information Society projects, has warned against the naive notion that ICTs can and will lead to large-scale elimination of social, educational and economic inequities. While a proponent of their wide-spread application she cautions that policy statements and declarations by ministers of economics affairs will fall far short of implementation without careful thought given to such matters as content, and protection and preservation of national and regional cultural and linguistic values.

The point has been made that African countries must develop their own version and vision of an information society; that the conceptions that we have emanate from the so-called first world countries with marked differences in terms of economic status, and development and educational levels, and consequently the needs of their citizens. Many pundits posit the so-called 'leapfrog approach' for the developing world to enter the information society. Negroponte (1998), the well-known Internet enthusiast, has conjured a dramatic illustration of the quantum of the leap for people in the developing world:

'In the comfort of being digital, we forget the enormous leverage a single connection provides to, say, a rural primary school in one of the hundred poorest nations. In these places, there are no libraries and almost no books; the schoolhouse is sometimes a tree. To suddenly have access to the world's libraries - even at 4800 bits per second - is a change of such magnitude that there is no way to understand it from the privileged position of the developed world'.

The leapfrog theory which has been fuelled by similar dramatic predictions has been more or less endorsed by some of the leaders in African countries. While it might provide a useful metaphor, indicating the possibility of rapid and agile movement towards a desired state, the concept is only useful to the extent that it suggests that there are certain iterations in the development of information technology and its manufacture that these countries do not need to concern themselves with; that developing countries are now in a position to exploit the fact that the cost of the technology has dramatically decreased making it possible to extend, for example, learning and educational opportunities to millions through the use of information technology.

The leapfrog theory should not be taken to mean that people can bypass the so-called traditional literacies of reading, writing and numeracy, and launch into computer literacy; nor that information technology will meet all their informational and reading needs. This is a fallacious approach. So while it is true that transferring the hard technologies to a country such as South Africa is essential, the leapfrog will only be effective if it is accompanied by the transfer (or use) of the 'soft' technologies - training, institutional capacity and infrastructure support (Energy Foundation 1997). The Energy Foundation (1997) points out that a major constraint in the successful development of developing countries' technological development has been 'the tendency of hard technologies to run ahead of the soft technologies that sustain them'. Knight, of the World Bank Group, makes a similar point when he notes that the 'software' of social, political, economic and organisational arrangement to permit this (the possibility of African students to access the world's knowledge base) are lagging behind the technological potential (Knight 1996).

Some of the challenges outlined by Anan at the Africa Telecom '98 Conference can be more easily tackled on a regional basis than by individual efforts. For example, the scarcity of bandwidth suggests that a co-operative and comprehensive approach might be more effective for the region as a whole to achieve interconnectivity of networks and interoperability of services. A scrutiny of the telecommunications indicators shows very clearly the leadership role of South Africa which has far greater capacity than the other countries in the region, and indeed the continent.

'With its low-cost international leased lines to neighbouring countries and excess telecoms bandwidth on the fibre link to Europe and the US, South Africa has become the Internet hub for the sub-region' (Jensen 1998).

In addition to the sharing of experience and best practice among African countries, partnerships between the public and private sector should also be encouraged (Amoako \& Faye 1998:18). Plans to put in 20 billion dollars worth of new telecommunications infrastructure by the year 2003 were announced at the Africa Telecom '98 conference (Gumede 
1998:5). In South Africa it is expected that in the next six years every citizen will have access to a telephone, by the installation of 3 million lines. Jay Naidoo, Minister of Posts, Telegraphs and Telecommunications, signalled the South African government's intention to

'use the power of the Internet to connect our people, to allow even the poorest of the poor access to global information. This must extend from Cape to Cairo' (Gumede 1998:5).

\section{Role of the government in realising the vision}

The recent activities in the field of telecommunications show that there has been progress with respect to liberalisation of government policies, and the removal of restrictive monopolies and the introduction of competition. This year the Minister of Posts, Telegraphs and Telecommunications, Minister Jay Naidoo, expressed his confidence in South Africa's capacity to join the information society in the next few years:

'I have made sure that all our efforts are aimed not only at bringing South Africa as a country into the information age, but also at giving universal access to telecommunications to thousands of communities. As a result, South Africa has one of the fastest rollout programmes in the world. Over the next five years 2,8 million new lines, including 120000 payphones and 1,6 million new lines will be installed in our townships and villages to bring telephone penetration in economically qualified households in all provinces to more that $50 \%$ (Naidoo 1998).

In the same speech he went on to identify libraries in underserviced areas as one of the priorities of the roll-out programme; others included schools, clinics, community centres and small villages. As part of his department's plans to accelerate progress towards universal access the Minister noted on a different occasion that more than 2000 schools will 'leapfrog' onto the Worldwide Web (Mohapeloa 1998).

The concept of universal service endorsed at the international meetings referred to above, has been adopted, and made concrete in South Africa in the establishment of the Universal Service Agency (USA). The United Service Agency (USA) has been mandated to create a national network of telecentres which will provide access to telephone and Internet services in underserved areas. The USA is the national agency, established by law,

'to promote and establish connectivity and universal access to communications for unconnected, underserviced, and mostly rural communities or townships. USA has decided to accomplish the goal of universal (national) access through the roll-out of 1000 telecentres by 1999 to communities already identified in a national master plan'.

This ambitious roll-out commenced in March 1998. It is envisaged that the plan will materialise only with substantial external support and funding (United Nations Development Programme 1998). Universal access is defined as the pre- sence of public access services within thirty minutes' walk from anywhere in the country (Jensen 1998). As a strategy for achieving its mandate the USA has decided to support the Multi-Purpose Community Centres (MPCCs) through the establishment of telecentres. The Telecentre Programme hopes to establish a thousand telecentres in 1998, mainly in the rural areas, to offer photocopying, phones, fax, e-mail, TV/video and Internet facilities (Jensen 1998). To ensure viability and sustainability, the USA notes that it will work in partnership with other organisations such as churches, libraries and schools so that a replicable model can be built up of running telecentres in the disadvantaged areas (Butcher 1998).

\section{Opportunities for libraries: Multi-Purpose Commu- nity Centres}

Some of the themes arising from the G7 conference, and echoed at the ISAD Conference, are particularly germane to the ways in which library and information services might assist facilitating the benefits to be derived from the widespread use of ICTs for development:

- promotion of diversity of content, including cultural and linguistic diversity;

- universal service as an essential pillar;

- serving the cultural enrichment of all citizens through diversity of content, reflecting linguistic and cultural diversity;

- acquisition of skills and adaptability through life-long education and training;

- tackling access through the provision of tools to citizens to learn in an information society; and

- development and acquisition of multimedia information services to meet these requirements, and to complement the traditional teaching and learning systems (G7 Ministerial Conference ... 1995).

The evidence is accruing that libraries have started to feature in the government's view of the unfolding information society. While they are not central in the vision, they at least occupy a niche. One of the most clearly expressed scenarios in which libraries feature is the Multi-Purpose Community Centre (MPCC) - it is up to librarians to seize and extend the opportunity to demonstrate the vital role that library and information services can and should play. A conference, Empowering Communities in the Information Society, which took advantage of the timing of the ISAD Conference, was held on 15-17 May 1996 in Pretoria to explore ways of empowering the people through the provision of information. An analysis of all the papers and inputs at the conference showed that the Multi-Purpose Community Centre was the most effective method of reaching all communities, whether rural or urban (Berlyn 1997). The configuration of services offered by such MPCCs would differ according to community, locality and needs, but could include telecommunications facilities, electronic libraries, telemedicine and the like. The contributory components could include schools, tertiary education, libraries, churches and clinics. MPCCs 
have received considerable attention because of the potential identified as a vehicle for development of communities, and because they were one of five South African Information Society Pilot Projects proposed by Deputy President Thabo Mbeki at the ISAD Conference. Since this conference in 1996 which identified the MPCC as one of the most effective methods of empowering communities through information, a survey has been conducted to determine the extent to which MPCCs have started operations in South Africa. The National Information Technology Forum conducted the national survey between April 1997 and February 1998. The results were reported in May 1998. Their definition of an MPCC is as follows:

'A MPCC is a structure which enables communities to manage their own development, by providing access to appropriate information, facilities, resources, training and services. It is also known as a Community Service Centre, Community Information Centre, Community Resource Centre, etc. It is a key component in RDP-related development, and integrated delivery of government services (National Information Technology Forum 1998:7).

For the purposes of the survey, the working definition was critical; it also offers useful pointers for public/community libraries interested in reconceptualising services to realigning them with RDP objectives. The definition they used was as follows:

'An MPCC is an organisation offering a range of developmental services (including information services) to a specific community and with a large degree of community involvement (National Information Technology Forum 1998:8).

The survey was concerned to discover the ways in which MPCCs acquire and provide information for community development. It was recognised that a lot of information would circulate in communities, but that MPCCs would offer formalised information systems, consisting of all media: paper, electronic and personal. Forty percent of the respondents included a library service among their services; other services included training, advice office, counselling and resource centre (1998:6). Among the findings that they report was the high percentage of the MPCCs in Gauteng which described themselves as libraries. The researchers note approvingly that

'A number of the MPCCs mentioned here are libraries as in Gauteng (in particular it seems) several libraries have made concerted efforts to open up their services and be responsive to the needs of the communities they serve' (National Information Technology Forum 1998:44).

A critical observer from the LIS sector might more readily judge that this is a very modest intervention for public libraries for whom the definition seems tailor made: serving communities by acting as a focal point for information in the community for development. Leaving aside logistical reasons which might account for such low figures (e.g. community libraries were not aware of the survey) reasons must be sought why public libraries are not considering themselves as MPCCs given the powerful political, economic, strategic and developmental reasons why they should. The answer is likely to lie in the criterion of strong community support/involvement/ownership. Harris interprets the criterion of being community-based as 'community ownership, community management [and] accountability' (quoted by Pateman 1998: 472). In addition to having the characteristic of being rooted in the community, libraries will be readily accepted as partners in the enterprise (given the emphasis on partnerships in the thinking) if they can demonstrate the social, educational and economic benefits for the communities, easing their way into the information society.

Much hard work will be required to develop the sense of community ownership, particularly in those areas where the levels of exclusion have been high, and where the profile of the library has been low. The role of the librarian will also change to incorporate the role of information/education facilitator with that of information organiser/manager accountable not only to traditional employing authority but also to the community groups being served. The characteristics of the MPCCs analysed for the identification of best practice in the survey include the initiation and maintenance of public/ private partnerships or consortial-type structures, a modality that is unusual in most public library operations. Librarians have in the past spent too much time in each others' company at professional meetings and the like, and too little time breaching the boundaries between our sector and the terrain of other groups. A preliminary evaluation of the G7 global information society projects (of which the MPCCs is one) has shown that the most visible advances have been in the logistical and technical areas involving specialist communities. The particular contribution that libraries can make is by making available not only the information resources, and the ICTs, but also empowering citizens to take up and use the resources by acquiring information literacy to give 'meaning and content to the concept of the information society for the citizen' (National Coordinators 1998).

\section{References}

Amoako, K. \& Faye, M. 1998. The Global Connectivity for Africa Conference, Addis Ababa, 2 to 4 June 1998: opening statement, summary and recommendations. Meta-information bulletin, 7(3):17 -21.

Bangemann, M. et al. 1994. Europe and the global information society. Recommendations to the European Council, 26 May 1994. Brussels: European Commission. (Unpublished).

Bangemann, M. 1995. Speech by M. Bangemann on the information society. [Online]. Available: http:// www.ispo.cec.be/infosoc/promo/speech/eurim.html

Bell, D. 1974. The coming of the post-industrial society: an adventure in social forecasting. London: Heinemann.

Berlyn, J. 1997. Empowering communities in society. Metainformation bulletin, 6:2. [Online]. Available: http:// www.librarynet. co.za/Meta-info_bulletin $1 . h$ tm 
Butcher, N. 1998. The possibilities and pitfalls of harnessing ICTs to accelerate social development: a South African perspective. [Online]. Available: http://www.saide.org.za/ conference/unrisd.htm

Chairperson's views concerning ideas emerging from the fora discussions on global information society and development themes and projects. 1996. A paper emerging from the Information Society and Development Conference, Midrand, May 1996. (Unpublished).

Energy Foundation. 1997. Policies to promote leapfrog technologies. [Online]. Available: http://www.ef.org.reports/ letV/

European Union. 1996. Green paper: Living and working in the information society: people first. Brussels: European Commission. [Online]. Available: http://www.ispo.cec.be/ infosoc/legreg/docs/peopl1st.html

European Union. High-Level Expert Group. 1997. Building the information society for us all. Brussels: European Commission. [Online]. Available: http://www.ispo.cec.be/ hleg/Building.html

G-7 Ministerial Conference on the Information Society (1995: Brussels). 1995. [Online]. Available: http://www.ispo.cec.be/ g7/keydocs/G7en.html

Gumede, W. 1998. Africa's dream trip over reality at telecom show. 1998. Sunday independent business. 16 May:5.

Hafkin, N. 1996. Seminar delivered at School of Librarianship, University of Cape Town. (Unpublished remarks and discussion).

Jensen, M. 1998. African Internet connectivity: paper on Sangonet web-site. [Online]. Available: http:// demiurge.wn.apc.prg:/africa/southafr.htm

Knight, P. 1996. Destined to leapfrog: why a revolution in learning will occur in Brazil, Russia and South Africa. Paper prepared for the Second International Conference on Distance Education in Russia, July 1996. [Online]. Available: http:// www.knight-moore.com/html/leapfrog.html

Mbeki, T. 1995. Speech of the Deputy President of the Republic of South Africa, Thabo Mbeki at the G-G7 Conference on the Information Society. [Online]. Available: http:// www.ispo.cec.be/g7/press/thabo.html
McColgan, C. 1996. Definition of information society. [Online]. E-mail message in the ISPO List Serv. Available: http://www. ispo.cec.be/ispo/lists/ispo96/1228.html

Mohapeloa, V. 1998. More than 2000 schools will 'leapfrog' on to the Web. SacomNews. [Online]. Available: http://www. gcis.gov.za/

Naidoo, J. 1998. Statement given by Jay Naidoo, Minister for Posts, Telecommunications and Broadcasting at the launch of the digital enhanced cordless (DECT) network, Khayelitsha, Western Cape, May 1998. [Online]. Available: http:// www.gcis.gov.za/cgi-bin/vdkw_cgi/xb349f7e4-446/Search/ $5228332 / 3$

Naisbitt, J. 1984. Megatrends: ten new directions transforming our lives. New York: Warner Books.

National Coordinators. Global Information Society Pilot Projects. 1998. G-8 global information society pilot projects. interim report. [Online]. Available: http://www.ispo.cec.be/ g7/g8interim.html

National Information Technology Forum. 1998. Multi-Purpose Community Centre: research report. [Online]. Available: http://wn.apc.org/nitf/mpcc/

Negroponte, N. 1998. The third shall be first: the net leverages latecomers in the developing world. [Online]. Available: http://www.alightintheattic.com/news/ wired\%20latecomers.html (Extract from an article for Wired magazine).

Pateman, J. 1998. Planning to tackle poverty. Library Association record, 100(9):472.

Thorhauge, J. et al. 1997. Public libraries and the information society. Luxembourg: European Commission.

Toffler, A. 1980. The third wave. London: Collins.

United Nations Development Programme. 1998. INFO 21. Pilot projects by UNDP's IT for Development Programme. [Online]: Available: http://www.undp.org/undp/info21/pilot/ pi-sa.html

Webster, F. 1995. Theories of the information society. London: Routledge. 